Original Article

\title{
Oceanographic variability and its influence on pelagic fish catch in the Bali Strait
}

\author{
Abu Bakar Sambah ${ }^{*}$, Trisnanda Devi Oktavia ${ }^{1}$, Denny Wijaya Kusuma ${ }^{2}$, Feni Iranawati ${ }^{1}$, Nurin Hidayati $^{1}$, Adi Wijaya $^{2}$ \\ ${ }^{1}$ Department of Fisheries and Marine Resources Utilization, Faculty of Fisheries and Marine Science, Universitas Brawijaya. Jl. Veteran Malang, \\ East Java 65145 \\ ${ }^{2}$ Institute for Marine Research and Observation, Jl. Baru, Perancak, Jembrana, Bali 82251
}

\begin{abstract}
Oceanographic factor influences the number of fish catch in Bali Strait, in which global phenomena such as El-Nino Southern Oscillation (ENSO) and the Indian Ocean Dipole (IOD) also have a role in influencing the migration of fish. This research aims to analysis annual variation of Sea Surface Temperature (SST) and Sea Surface Chlorophyll-a (SSC) in Bali Strait, and its effect on fish catch. The method applied a quantitative descriptive with correlation analysis and spatial analysis using Geographical Information System. The analysis described a significant impact of oceanographic parameters on pelagic fish catch. SST described a negative correlation, in which the higher the SST, the lower the catch and vice versa. There was a time lag between SST and catch when the upwelling process occurs which was followed by an increase in SSC concentration and catch. SSC has a significant impact on the number of fish catch which describes a positive correlation, and it illustrated a time interval between the highest concentration of SSC and the period of fishing peak season. The intensity of upwelling refers to the variability of SST by physical and dynamic processes of water, which also affected by the ENSO and the Indian Ocean Dipole IOD.
\end{abstract}

Keywords: Fishing ground, oceanographic variability, pelagic fish

Received: 21 August 2020 Revised: 04 October 2020 Accepted: 12 October 2020

\section{Introduction}

Lemuru (Sardinella lemuru) fishery resource is the most dominant and economically valuable fishery resource in the Bali Strait, so that this commodity is mostly exploited by fishermen who live around the Bali Strait. In addition, lemuru fisheries have an important role in the life of the local community. Another benefit of the lemuru fishery business is as a source of regional income, supporting local industries, and increasing employment (Joesidawati et al., 2004). According to Merta (2003) lemuru is a schooling species in shallow sea waters, in coastal areas at a depth of less than 60 meters, and often migrate to lagoons, bays or river estuaries. The distribution of lemuru fish in the Bali Strait is spread along the west coast of Bali Island and the east coast of Banyuwangi. The migration pattern of lemuru is strongly influenced by oceanographic conditions; with the peak migration is estimated on December to January. Studies related to the observation of oceanographic condition at lemuru fishing ground around Bali Strait are limited. This information is very important to identify environmental factors that affect the existence and abundance of lemuru in the Bali Strait in order to map the potential fishing ground of lemuru for sustainable management.

Oceanographically, Indonesian waters, including the Bali Strait, are influenced by the seasonal cycle, namely the eastern monsoon (southeast monsoon) and west monsoon (northwest monsoon). The east season occurs

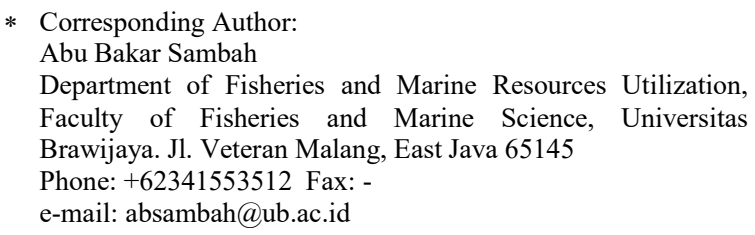

in June - September, while the west season occurs in December - March. The oceanographic conditions of the Bali Strait are also influenced by the El Niño Southern Oscillation (ENSO) and the Indian Ocean Dipole (IOD). This condition causes upwelling phenomena in the Bali Strait. The upwelling area is a potential area for fisheries activities due to the rich of nutrients for the survival of larvae, juveniles, and adult fish (Hendiarti et al., 2004; Hendiarti et al., 2005; Susilo, 2015).

The approaches for observing ocean and its phenomena recently have been done through the application of satellite imagery due to the ability of satellites cover large areas. Ocean remote sensing is able to provide data on a global scale on the surface layer of the waters in near real time. Oceanographic satellite data can be used to monitor various marine phenomena such as upwelling, eddy, front and altimetry which are closely related to fishery activities (Robinson, 2010). Ocean remote sensing technology allows monitoring of the variability of environmental conditions to be carried out more efficiently and quickly.

Geographical differences are a major factor in finding the existence of lemuru habitats. Lemuru fish are mostly found in the Bali Strait with a migration pattern that reaches its peak in June - November which is influenced by the east monsoon winds so that in that month the lemuru is very abundant in the Bali Strait. Temperature and salinity have an inverse relationship where if the temperature has a maximum value then the salinity has a minimal value. These variations can determine the density of seawater which affects the vertical motion of the seawater masses. Chlorophyll-a also plays as an important factor in phytoplankton during photosynthesis, and together with other oceanographic factors can be used in predictive studies of marine resources. 
Sea Surface Temperature (SST) is associated as an index of the amount of water vapor that forms clouds in the atmosphere. If the SST is hot, there is a lot of water vapor in the atmosphere due to the convection or evaporation process. Conversely, if the SST is cold, water vapor in the atmosphere is reduced due to lack of evaporation. The SST in the territory of Indonesia has a fairly wide range of $26.0{ }^{\circ} \mathrm{C}$ to $31.5{ }^{\circ} \mathrm{C}$ (Syaifullah, 2018). Moreover, Chlorophyll-a is an active pigment in plant cells that has an important role in the process of photosynthesis in waters which can be used as an indicator of whether or not there are many fish in an area from the description of the food chain cycle that occurs in the ocean. The concentration of chlorophyll-a in water depends on the availability of nutrients and the intensity of sunlight. If enough nutrients and sun intensity are available, the chlorophyll-a concentration will be high and vice versa (Effendi et al., 2012).

In order to create good management of lemuru fish in Bali Strait, a holistic approach must be taken. This study tries to analyze the inter-annual variability of oceanographic factors and its relationship to lemuru habitat in order to contribute in preparing basic information for sustainable fisheries management in Bali Strait.

\section{Methods}

The research was conducted in the Bali Strait with the boundaries of $144^{\circ} 21^{\prime}-115^{\circ} 11^{\prime}$ East Longitude and $8^{\circ} 6^{\prime}-8^{\circ} 6^{\prime}$ South Latitude (Figure 1). Data collection and initial data processing were carried out at the Institute for Marine Research and Observation, Bali, as a research partner. Advanced data processing and data analysis were carried out in the Fisheries and Marine Resources Exploration Laboratory, Faculty of Fisheries and Marine Sciences, Universitas Brawijaya. Fish catch data series was taken from fishing ports along coastal area of the Bali Strait, and these applied also as the parameter in mapping processing. Moreover, oceanographic variables are obtained from MODIS Aqua/Terra sensors with a spatial resolution of $4 \mathrm{~km}$ and a global equidistant cylindrical geometric projection. These variables include SST $\left({ }^{\circ} \mathrm{C}\right)$ and Sea Surface Chlorophyll-a/SSC $\left(\mathrm{mg} / \mathrm{m}^{3}\right)$. The data was obtained by downloading from the Ocean Color homepage (http://oceancolor.gsfc.nasa.gov/), and was processing using SeaDAS and Geographical Information System software.

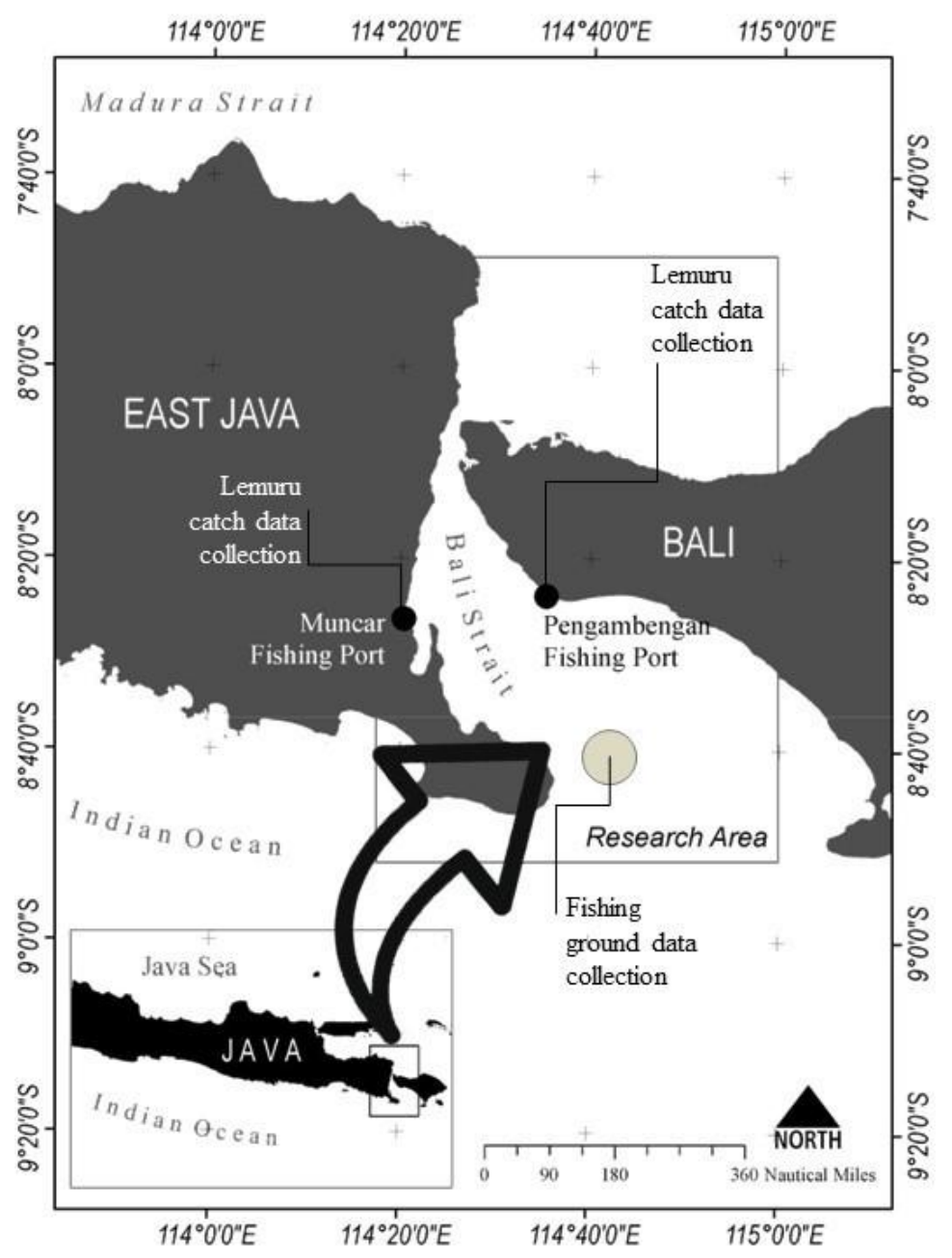

Figure 1 Research area (Bali Strait) 
SST from MODIS Aqua/Terra sensors was calculated using the algorithm derivation of brightness temperature as below;

\section{dBT $=$ BT39 - BT40}

in which, dBT is the brightness level of the color temperature. The value of BT39 $=3.959 \mu \mathrm{m}$ and the value of BT40 $=4.050 \mu \mathrm{m}$. Furthermore, the SST value can be obtained with the following equation; 1.0

$\mathrm{SST} 4=\mathrm{a} 0+\mathrm{a} 1 \times \mathrm{BT39}+\mathrm{a} 2 \times \mathrm{dBT}+\mathrm{a} 3 \times 1.0 / \mu-$

$\mu$ is the Zenith angle level while the values a0, a1, a2 and $\mathrm{a} 3$ are in accordance with the values set by RSMAS (Rosenstiel School of Marine and Atmospheric Science) based on the values or brightness levels that have been obtained.

The SST derived from measurements of the MODIS infrared radiometers is commonly referred to as the skin temperature of the ocean, in which the radiance measured by infrared radiometers originates in the surface skin layer of the ocean and not the body of water below as measured by in situ measurement (Donlon et al., 2007). The MODIS SST4 algorithm and quality assessment are the responsibility of the MODIS Science Team Lead for SST (currently P. Minnett of the RSMAS at the University of Miami (Minnett et al., 2004).

In addition, SSC can be obtained from the Aqua MODIS satellite using the following algorithm:

$$
\mathbf{C a}=\frac{\operatorname{10}^{(\mathrm{a} 0+\mathrm{a} 1 \mathrm{R}+\mathrm{a} 2 \mathrm{R2}+\mathrm{a} 3 \mathrm{R} 3+\mathrm{a} 4 \mathrm{R} 4)}}{\log _{10} \operatorname{RrS}_{443}>\operatorname{RrS}_{\mathbf{4 8 5}}}
$$

In which, $\mathrm{Ca}$ is chlorophyll-a concentration $\left(\mathrm{mg} / \mathrm{m}^{3}\right)$, $\mathrm{R}$ is reflectance ratio, and Rrs is Remote Sensing Reflectance. Rrs has wavelengths ranging from 440 to 70 $\mathrm{nm}$. The data of this study used Rrs (blue) with a range of 443 and Rrs (green) with a range of 488, while Rrs551 was defined as a surface reflectance value at a wavelength of $551 \mathrm{~nm}$, and the values a 0 is 547 and ai is 0.242 .

Furthermore, correlation analysis in order to measure the closeness of the relationship between research variables was carried out. The strength of the relationship between two variables can be measured. An index that measures the closeness of the relationship between two variables is called the correlation coefficient (Nugroho et al., 2008). The calculated number correlation method is the relation coefficient (r), as shown in the following formula:

$$
\mathbf{r}=\frac{n \sum x y-\left(\sum x\right)\left(\sum y\right)}{\sqrt{\left(n\left(\sum x^{2}\right)\left(n \sum y^{2}-\left(\sum y\right)^{2}\right)\right.}}
$$

$r$ is correlation coefficient, $x$ is oceanographic parameters, and y is catch.

The correlation coefficient (r) varies from 0 to +1 or 1. When the $r$ value approaches +1 , the relationship between the variables is strong and forms a positive curve. $\mathrm{R}$ values close to -1 also indicate a strong relationship between variables but forms a negative curve. If the value of $r$ approaches zero, the relationship between variables is weak (Walpole, 2012).

Spatial analysis with Geographical Information System approach was carried out in order to map the annual variability of oceanographic parameters and the potential fishing ground of lemuru fish. Spatial analysis is a type of geographical analysis which seeks to explain patterns of geographical phenomena (in this study includes oceanographic and fish habitat) and its spatial expression in terms of mathematics and geometry, that is, locational analysis.

In the mapping process for creating habitat suitability of lemuru fish as the potential fishing ground, a mapping analysis through weighted overlay was carried out. Weighted overlay is a technique for applying a rating scale to differentiate and unequal input into an integrated analysis. Weighted overlay gives consideration to the factors or criteria that are determined in a suitability selection process (Willige, 2010; Sofyan et al., 2010). The weighted overlay tool of Geographical Information System applies one of the most used approaches for overlay analysis to solve multi-criteria problems; in case of this study is an analysis of habitat suitability models of lemuru fish. The higher values as the result of weighted overlay indicate that a location is more suitable. In general, research flow diagram that described the step of method applied as illustrated in Figure 2.

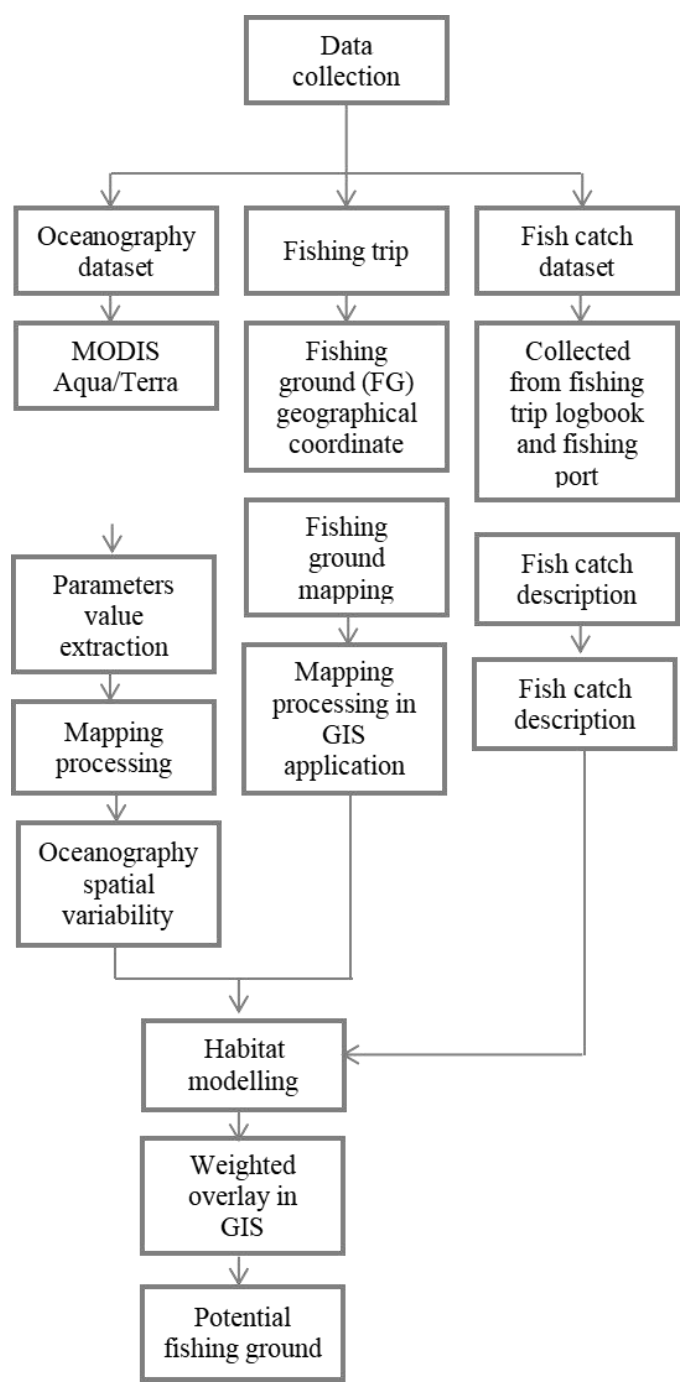

Figure 2. Research flow diagram 


\section{Results}

\section{Oceanographic Variability}

The Bali Strait is one of the waters that separate the islands of Java and Bali and has a fairly high fertility rate. The highest water fertility level in the Bali Strait occurs during the eastern monsoon where upwelling occurs so that the dominant nutrients consisting of phosphate and nitrate in the waters are quite high and the abundance of phytoplankton. This is because the Bali Strait directly connects the Indian Ocean in the south and the Madura Strait in the north so that the water mass in the waters in the Bali Strait is more dominantly influenced by water masses from the Indian Ocean. The highest average of SST value was found in 2012 , namely $30.65{ }^{\circ} \mathrm{C}$ and the lowest in 2017 of $27.63{ }^{\circ} \mathrm{C}$. During the year of $2010-$ 2019, the SST of Bali Strait is experiencing significant fluctuations. In 2010 - 2013 the temperature range in the Bali Strait was relatively high, namely $\pm 30{ }^{\circ} \mathrm{C}$ due to La Nina phenomena which causes more warm water masses to be carried to the western part of the Pacific Ocean so that there is an increase in rainfall. The variation of SST as described in Figure 3.

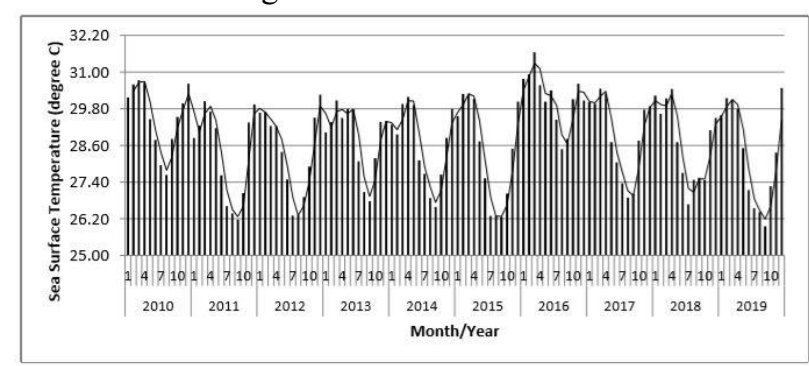

Figure 3. The variation of SST during 2010-2019 around Bali Strait

Moreover, chlorophyll-a is one of the most important parameters that determine primary productivity at sea. The distribution and level of SSC concentrations are closely related to the oceanographic conditions. The highest SSC concentration value in the Bali Strait was in $2015\left(0.64 \mathrm{mg} / \mathrm{m}^{3}\right)$ and the lowest was in $2012(0.25$ $\left.\mathrm{mg} / \mathrm{m}^{3}\right)$. The concentration of SSC in the Bali Strait during the period of 2010 - 2019 was quite stable, but in 2015 it experienced a high enough increase due to the influence of El-Nino which caused the water temperature in the Bali Strait to be quite low. The variation of SSC as described in Figure 4.

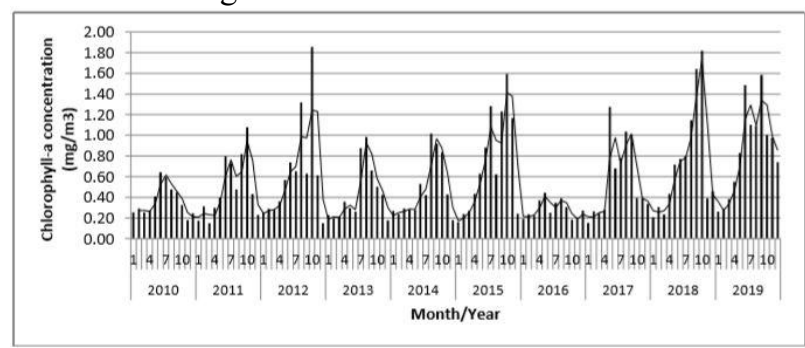

Figure 4. The variation of SSC during 2010-2019 around Bali Strait

\section{Relationship between oceanographic parameters}

The analysis of oceanographic relationship was done for the period data of $2010-2019$. The SST values in the Bali Strait ranged from $27.63-30.65{ }^{\circ} \mathrm{C}$ while for SSC values in the Bali Strait ranged from 0.25 to $0.64 \mathrm{mg} / \mathrm{m}^{3}$.
The high and low SST and SSC were influenced by the upwelling phenomenon which causes a decrease in SST and the high nutrient content which is rich in nutrients reaches the surface of the water, so that high amounts of nutrients will be followed by an increase in the chlorophyll-a content in these waters (Graph in Figure 5).

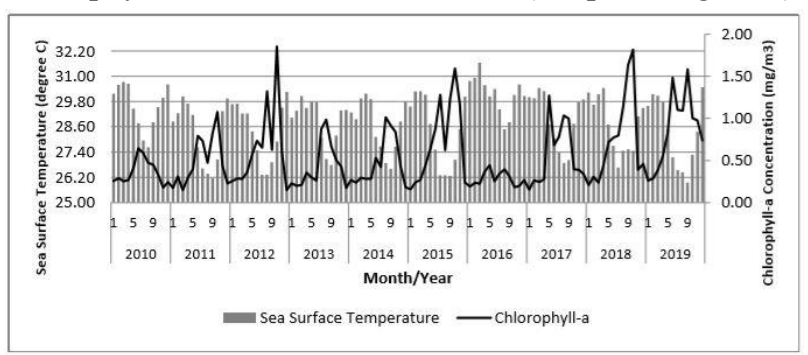

Figure 5. Relationship between oceanographic parameters during 2010-2019 around Bali Strait

Pearson correlation is a simple correlation involving only the independent variable (independent) and the dependent variable (dependent). The results of the correlation value of the relationship between oceanographic parameters carried out in this study are presented in Table 1. SST and SSC have a very strong correlation with a correlation value of 0.748 and the form of the relationship is negative, meaning that the higher the SST value, the lower the SSC value.

\section{Lemuru catch and its relationship to oceanographic parameters}

Lemuru fish is a small pelagic fish that has high economic value for the people of Pengambengan and Muncar. Lemuru fish catch data was taken from Pengambengan fishing port in Jembrana Bali and Muncar fishing port in Banyuwangi (Figure 6). Catch data obtained for a period of 10 years, starting from 2010-2019. The highest catch recorded at Pengambengan fishing port was in 2017 (1702,525 tons) and the lowest average value was in 2012 (209,308 tons), while the highest catch recorded at Muncar fishing port was in 2014 (809,117 tons). The significant increase in 2017 was due to the distribution of fishing ground map around Bali Strait areas done by the Institute for Marine Research and Observation, Bali, Indonesia.

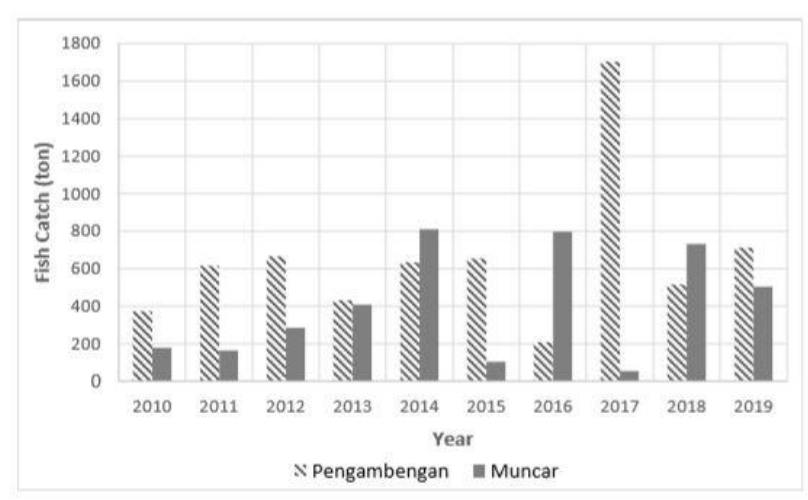

Figure 6. Lemuru fish catch data from 2010-2019 
Table 1. Correlation result of oceanographic parameters

\begin{tabular}{llrr}
\hline & & SST $\left({ }^{\circ} \mathrm{C}\right)$ & \multicolumn{2}{c}{$\mathrm{SSC}\left(\mathrm{mg} / \mathrm{m}^{3}\right)$} \\
\hline $\mathrm{SST}\left({ }^{\circ} \mathrm{C}\right)$ & Pearson Correlation & 1 & $(-) .748^{* *}$ \\
& Sig. (2-tailed) & & .000 \\
& $\mathrm{~N}$ & 120 & 120 \\
\hline $\mathrm{SSC}\left(\mathrm{mg} / \mathrm{m}^{3}\right)$ & Pearson Correlation & $(-) .748^{* *}$ & 1 \\
& Sig. (2-tailed) & .000 & 120 \\
& $\mathrm{~N}$ & 120 & \\
& & &
\end{tabular}

Table 2. The correlation between oceanographic parameters and the catch of lemuru fish in the Bali Strait

(a) $\operatorname{SST}\left({ }^{\circ} \mathrm{C}\right)$ and fish catch

\begin{tabular}{|c|c|c|c|}
\hline & & $\operatorname{SST}\left({ }^{\circ} \mathrm{C}\right)$ & Fish catch \\
\hline \multirow[t]{3}{*}{$\operatorname{SST}\left({ }^{\circ} \mathrm{C}\right)$} & Pearson Correlation & 1 & $(-) .878 * *$ \\
\hline & Sig. (2-tailed) & & .001 \\
\hline & $\mathrm{N}$ & 10 & 10 \\
\hline \multirow[t]{3}{*}{ Fish catch } & Pearson Correlation & $(-) .878^{* *}$ & 1 \\
\hline & Sig. (2-tailed) & .001 & \\
\hline & $\mathrm{N}$ & 10 & 10 \\
\hline
\end{tabular}

(b) $\mathrm{SSC}\left(\mathrm{mg} / \mathrm{m}^{3}\right)$ and fish catch

\begin{tabular}{|l|l|r|r|}
\hline \multicolumn{1}{|l|}{} & SSC $\left(\mathrm{mg} / \mathrm{m}^{3}\right)$ & \multicolumn{1}{|c|}{ Fish catch } \\
\hline SSC $\left(\mathrm{mg} / \mathrm{m}^{3}\right)$ & Pearson Correlation & 1 & $.657^{*}$ \\
\cline { 2 - 4 } & Sig. (2-tailed) & 10 & .039 \\
\cline { 2 - 4 } & $\mathrm{N}$ & $.657 *$ & 10 \\
\hline Fish catch & Pearson Correlation & .039 & 1 \\
\cline { 2 - 4 } & Sig. (2-tailed) & 10 & 10 \\
\cline { 2 - 4 } & $\mathrm{N}$ & & \\
\hline
\end{tabular}

The results of the significant value of SST and catch in this study were 0.001 . The value of less than 0.05 indicates that SST and catch had a correlation. The pearson correlation of SST value and the catch was 0.878 and indicates very strongly correlated, but the type of correlation was negative. It means that the higher the SST, the lower the catch and vice versa. There was a time lag between SST and catch when the upwelling process occurs which is followed by an increase in SSC so that the catch also increases. In addition, there was also a correlation between SSC and lemuru catches in the Bali Strait. The relationship between SSC and catch has a strong correlation with the form of a positive relationship. It means that the higher the value of $\mathrm{SSC}$, the higher the catch. The SSC concentration does not directly affect lemuru catch but requires a time lag. The correlation between SSC concentration and lemuru production was positive and will be significant in two to six months. The results of the correlation between oceanographic parameters and the catch of lemuru fish in the Bali Strait are presented in Table 2.

\section{Potential lemuru fishing ground}

Variations in oceanographic conditions play an important role in natural fluctuations of fish stocks, SST and SSC which have the greatest impact on the distribution of small pelagic fish. Thus, SST is a good indicator of a fishing ground and has been used for decades by fishermen and researchers. In addition, changes in environmental factors (physical and biological) may have profound effects on fish migration and growth patterns (Murase et al., 2009). The research collected around 30 main fishing grounds in the Bali Strait, which spread over a geographic location of $8^{\circ} 30^{\prime}$ 3.89 " S - $8^{\circ} 54^{\prime} 6.07^{\prime \prime} \mathrm{S}$ and $114^{\circ} 35^{\prime} 15.61^{\prime \prime} \mathrm{E}-114^{\circ} 44^{\prime}$ 9.46" E (Table 3). This data was collected through fishing trip activities. It shows that the point of fishing setting tends to move to the south area close to the Indian Ocean (Figure 7).

Together with oceanographic and fish catch data, the fishing ground map applied in the modelling of potential fishing ground in Bali Strait through mapping processing. All of these parameters were processed through a weight overlay approach to produce a lemuru fish suitability habitat as shown in Figure 8. Almost the same as the distribution of fishing grounds in the Bali Strait, the results of potential fishing ground mapping of lemuru fish in the Bali Strait in one year by considering the annual variation in oceanographic factors also show that the potential areas tend to spread to the south approaching Indian Ocean, there were even some areas that are included in the south waters of Java Island. The map in Figure 8 showed that during June until August the potential fishing ground of lemuru fish in Bali Strait tent to increase. The widest potential fishing ground was in July and declining slowly in September until the end of year. This is closely related to the catch report. It was reported from catch recorded at Pengambengan Fishing 
Port of Bali that the production of lemuru fish landed at the fishing port started to increase in July and peaked in August. The catch will start to decline slowly from
September to December. There was a time lag of about one month between the modeling results of the potential fishing ground mapping and the catch report.

Table 3. Geographical position of fishing ground in Bali Strait

\begin{tabular}{|c|c|c|c|c|}
\hline No & Latitude & Longitude & the average of SST $\left({ }^{\circ} \mathrm{C}\right)$ & the average of $\mathrm{SSC}\left(\mathrm{mg} / \mathrm{m}^{3}\right)$ \\
\hline 1 & $8^{\circ} 30^{\prime} 3.89 " \mathrm{~S}$ & $114^{\circ} 35^{\prime} 15.61^{\prime \prime E}$ & 30.29 & 0.30 \\
\hline 2 & $8^{\circ} 30^{\prime} 54.60^{\prime \prime S}$ & $114^{\circ} 37^{\prime} 8.05^{\prime \prime} \mathrm{E}$ & 30.15 & 0.36 \\
\hline 3 & $8^{\circ} 31 ' 38.97 " \mathrm{~S}$ & $114^{\circ} 34^{\prime} 21.84^{\prime \prime} \mathrm{E}$ & 29.97 & 0.39 \\
\hline 4 & $8^{\circ} 34^{\prime} 42.15^{\prime \prime S}$ & $114^{\circ} 36^{\prime} 16.58^{\prime \prime} \mathrm{E}$ & 29.45 & 0.23 \\
\hline 5 & $8^{\circ} 35^{\prime} 52.97 " \mathrm{~S}$ & $114^{\circ} 37^{\prime} 59.01^{\prime \prime} \mathrm{E}$ & 29.78 & 0.22 \\
\hline 6 & $8^{\circ} 32^{\prime} 45.74^{\prime \prime} \mathrm{S}$ & $114^{\circ} 39^{\prime} 36.86^{\prime \prime} \mathrm{E}$ & 29.34 & 0.44 \\
\hline 7 & $8^{\circ} 34^{\prime} 16.33^{\prime \prime S}$ & $114^{\circ} 40^{\prime} 34.01^{\prime \prime} \mathrm{E}$ & 29.45 & 0.27 \\
\hline 8 & $8^{\circ} 34^{\prime} 56.59 " \mathrm{~S}$ & $114^{\circ} 42^{\prime} 18.60^{\prime \prime} \mathrm{E}$ & 28.30 & 0.42 \\
\hline 9 & $8^{\circ} 38^{\prime} 24.75^{\prime \prime S}$ & $114^{\circ} 40^{\prime} 2.64^{\prime \prime E}$ & 29.05 & 0.28 \\
\hline 10 & $8^{\circ} 38^{\prime} 15.90^{\prime \prime S}$ & $114^{\circ} 42^{\prime} 33.70^{\prime \prime E}$ & 28.55 & 0.28 \\
\hline 11 & $8^{\circ} 38^{\prime} 14.74^{\prime \prime} \mathrm{S}$ & $114^{\circ} 45^{\prime} 59.99^{\prime \prime} \mathrm{E}$ & 28.34 & 0.24 \\
\hline 12 & $8^{\circ} 38^{\prime} 18.80^{\prime \prime} \mathrm{S}$ & $114^{\circ} 49^{\prime} 40.90^{\prime \prime} \mathrm{E}$ & 28.23 & 0.35 \\
\hline 13 & $8^{\circ} 48^{\prime} 59.48^{\prime \prime} \mathrm{S}$ & $114^{\circ} 38^{\prime} 31.76^{\prime \prime} \mathrm{E}$ & 29.03 & 0.57 \\
\hline 14 & $8^{\circ} 51^{\prime} 36.67 " \mathrm{~S}$ & $114^{\circ} 33^{\prime} 51.58^{\prime \prime} \mathrm{E}$ & 28.76 & 0.61 \\
\hline 15 & $8^{\circ} 43^{\prime} 8.12^{\prime \prime S}$ & $114^{\circ} 43^{\prime} 46.32^{\prime \prime} \mathrm{E}$ & 27.89 & 0.69 \\
\hline 16 & $8^{\circ} 51^{\prime} 16.84 " \mathrm{~S}$ & $114^{\circ} 30^{\prime} 4.18^{\prime \prime} \mathrm{E}$ & 28.93 & 0.77 \\
\hline 17 & $8^{\circ} 45^{\prime} 31.67 " \mathrm{~S}$ & $114^{\circ} 43^{\prime} 1.70^{\prime \prime} \mathrm{E}$ & 28.34 & 0.54 \\
\hline 18 & $8^{\circ} 48^{\prime} 11.21 " \mathrm{~S}$ & $114^{\circ} 42^{\prime} 12.47^{\prime \prime E}$ & 27.67 & 0.30 \\
\hline 19 & $8^{\circ} 51^{\prime} 9.33^{\prime \prime S}$ & $114^{\circ} 41^{\prime} 13.15^{\prime \prime} \mathrm{E}$ & 27.55 & 0.41 \\
\hline 20 & $8^{\circ} 44^{\prime} 40.41^{\prime \prime S}$ & $114^{\circ} 49^{\prime} 8.10^{\prime \prime} \mathrm{E}$ & 28.04 & 0.94 \\
\hline 21 & $8^{\circ} 47^{\prime} 26.74 " \mathrm{~S}$ & $114^{\circ} 49^{\prime} 30.28^{\prime \prime} \mathrm{E}$ & 27.43 & 1.21 \\
\hline 22 & $8^{\circ} 39^{\prime} 31.33 " \mathrm{~S}$ & $114^{\circ} 53^{\prime} 17.94^{\prime \prime} \mathrm{E}$ & 28.44 & 1.04 \\
\hline 23 & $8^{\circ} 43^{\prime} 0.46^{\prime \prime S}$ & $114^{\circ} 53^{\prime} 36.83^{\prime \prime} \mathrm{E}$ & 27.69 & 1.58 \\
\hline 24 & $8^{\circ} 46^{\prime} 36.61^{\prime \prime S}$ & $114^{\circ} 53^{\prime} 34.44^{\prime \prime E}$ & 27.23 & 0.88 \\
\hline 25 & $8^{\circ} 50^{\prime} 22.79^{\prime \prime} \mathrm{S}$ & $114^{\circ} 55^{\prime} 46.87^{\prime \prime} \mathrm{E}$ & 28.13 & 0.71 \\
\hline 26 & $8^{\circ} 53^{\prime} 15.42^{\prime \prime} \mathrm{S}$ & $114^{\circ} 57^{\prime} 49.85^{\prime \prime} \mathrm{E}$ & 28.53 & 0.90 \\
\hline 27 & $8^{\circ} 54 ' 24.66^{\prime \prime S}$ & $115^{\circ} 1 ' 24.05^{\prime \prime E}$ & 27.77 & 1.00 \\
\hline 28 & $8^{\circ} 55^{\prime} 37.82 " \mathrm{~S}$ & $115^{\circ} 5^{\prime} 48.37^{\prime \prime} \mathrm{E}$ & 28.76 & 1.67 \\
\hline 29 & $8^{\circ} 51^{\prime} 14.76 " \mathrm{~S}$ & $114^{\circ} 50^{\prime} 10.18^{\prime \prime} \mathrm{E}$ & 29.34 & 0.80 \\
\hline 30 & $8^{\circ} 54^{\prime} 6.07^{\prime \prime S}$ & $114^{\circ} 44^{\prime} 9.46^{\prime \prime} \mathrm{E}$ & 28.12 & 0.66 \\
\hline
\end{tabular}

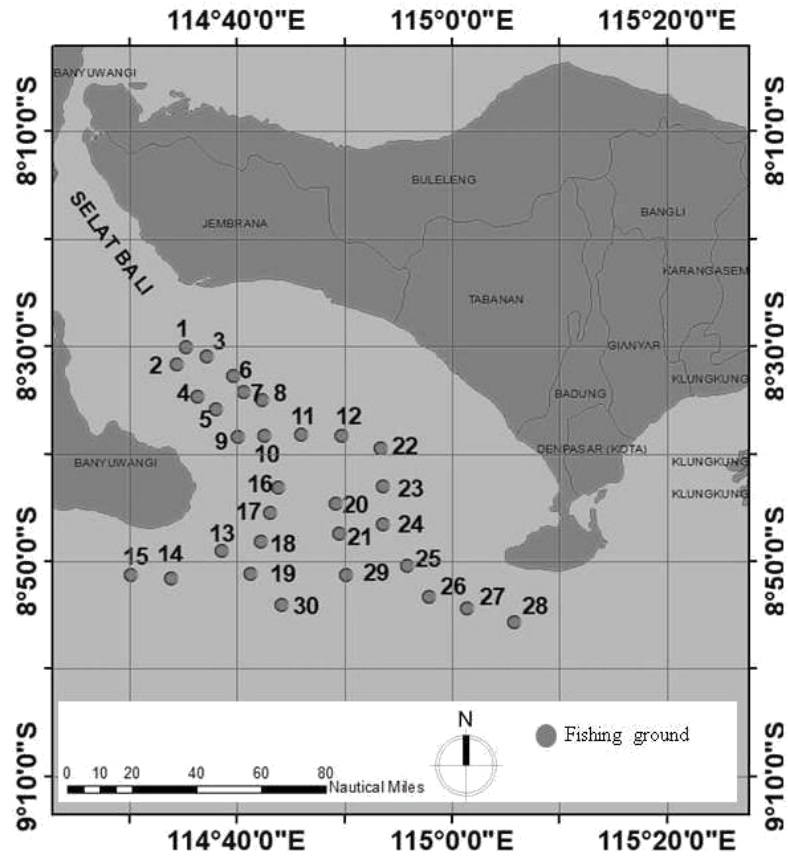

Figure 7. Fishing grounds in Bali Strait
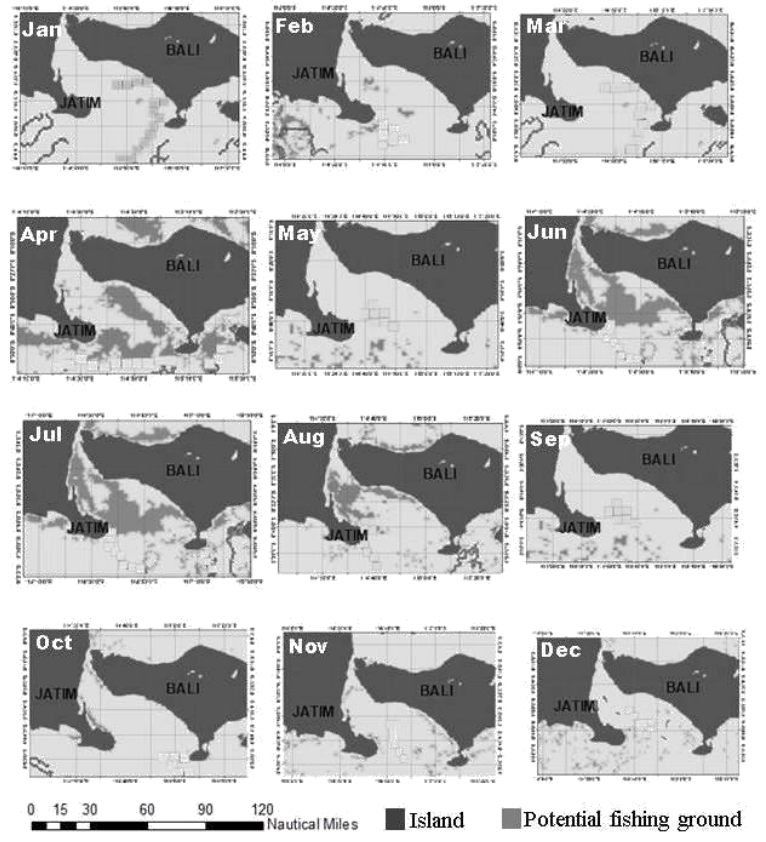

Figure 8. Potential fishing grounds in Bali Strait 


\section{Discussion}

Temperature is an indication of the presence of fish groups in an area, but sea surface temperature is greatly influenced by changes in other environmental waters, including: currents, winds, and exposure to direct sunlight, while lemuru is a type of fish that is sensitive to environmental changes (Rahadian et al., 2019). Sea surface temperature and chlorophyll-a are the main indicators in determining the occurrence of upwelling in waters, where upwelling is characterized by lifting cold water masses from the bottom to the surface which causes a decrease in SST and an increase in the concentration of water chlorophyll (Hendiarti et al., 2005). According to Susanto and Marra (2005) during the blowing of the southeast monsoon from April to October, the southeast wind from Australia drives upwelling, bringing cooler water and increasing nutrients to sea level along the Southern Waters of Java-Bali. Conditions reverse during the blowing of the west monsoon (October-March). The intensity of upwelling refers to the rate of decrease in surface temperature by physical and dynamic processes of water, which can be strengthened or weakened by phenomena such as the ElNino Southern Oscillation (ENSO) in the Pacific Ocean and the Indian Ocean Dipole (IOD) in the Indian Ocean (Kemili \& Putri, 2012). Indonesia waters are very vulnerable to climate or weather change. The weather anomalies that happened in 2016/2017 was caused by natural phenomena, namely the El Nino and La Nina and also the changes in SST (Hayati, 2017)

Chlorophyll-a is a pigment from phytoplankton that plays a role in the photosynthesis process. Chlorophyll-a is also used as an indicator of water fertility, which is indicated by the SSC concentration in these waters. The waters of the Bali Strait have more diverse SSC concentration stratifications in the southern part which represent the Indian Ocean as the entrance and exit for the circulation of water masses and the mixing of water masses can affect the primary productivity of the waters. The concentration of SSC in the waters of the Bali Strait is influenced by the mass of water that enters and leaves the strait, where the water mass comes from the surface water mass, so that the availability of nutrients in the deeper water column does not come out following the movement of the water mass (Priyono et al., 2007).

In addition, particulate organic carbon is also can used as a parameter for waters in the Bali Strait because it has an indirect relationship with the distribution of SSC. Particulate organic carbon is the form of carbon most prone to sedimentation and plays an important role in absorbing carbon and compounds. The range of SSC and particulate organic carbon concentrations shows the physical and biological diversity of the coast (rivers, abundance of phytoplankton, areas affected by sediment and upwelling) with particulate carbon concentrations $<100 \mu \mathrm{g} \mathrm{L}-1$ (Tran et al., 2019). Thus, the particulate carbon in the area close to chlorophyll-a has an impact on the abundance of phytoplankton so that chlorophyll-a is the main source of production particles (Furuya, 1990). The photosynthesis process itself is influenced by the concentration of SSC and the intensity of sunlight. The value of aquatic productivity can be used as an indication of the fertility level of waters. The value of water productivity is directly proportional to the amount of organic matter composition. This shows that the more organic matter in waters, the higher the productivity of the waters, where the productivity of the waters is a process of forming organic compounds through the process of photosynthesis (Yuningsih et al., 2014; Barus et al., 2008).

The increase in the value of SSC concentration does not directly affect the increase in the fish catch value, but it takes some time so that the existing chlorophyll-a has been used by zooplankton as a food source (Sartimbul et al., 2010; Putra et al., 2012). Season and fishing ground are closely related to fish migration. Fish will seek and select a certain optimum combination of physical and biological conditions in an aquatic environment. Lemuru fish are schooling small pelagic fish, which can form a high biomass in waters where upwelling occurs such as in the waters of the Bali Strait (Merta \& Nurhakim, 2017). The peak season for lemuru fishing occurs in November (the East-West transitional season). The trend of fishing season patterns that indicate the most appropriate time or season to catch lemuru (Simbolon et al., 2011). The fishing ground is based on several indicators, namely the amount of catch and SST. Based on the pattern of SST distribution, the temperature in the western monsoon tends to be warm, especially from February to April (Rahadian et al., 2019).

Mapping of potential areas for pelagic fish can be done with remote sensing technology. One of which is by identifying SST with an optimum temperature of 20$30{ }^{\circ} \mathrm{C}$ (Zahroh \& Sukojo, 2016), and SSC concentrations ranging from 0.2 to $3.5 \mathrm{mg} / \mathrm{m}^{3}$. The stratification of the SSC distribution pattern at each depth shows that the SSC concentration decreases with increasing depth (Hastuti et al., 2016). These two oceanographic parameters will then be analyzed according to their suitability with the general fishing ground of fishermen in the Bali Strait. Apart from these two parameters, the spatial distribution of surface particulate organic carbon concentrations in the sea can also be considered, and is generally regulated by both biological processes, especially in primary production and physical processes, especially mixing and vertical advection (Stramska, 2014).

The Bali Strait has also been influenced by regional phenomena such as the El Niño Southern Oscillation (ENSO) and the Indian Ocean Dipole (IOD). The characteristics of the waters of the Bali Strait are characterized by low salinity and cold temperatures. The Bali Strait has also been influenced by the Indonesian Cross Flow (ARLINDO) and mixing in the Pacific Ocean (Kunarso et al., 2011). The high concentration of SSC in the Bali Strait is an interaction between ENSO and IOD. ENSO and IOD climate phenomena are increasingly occurring with increasingly extreme conditions and longer duration; so that they have a very significant impact on lemuru fish catch. 


\section{Acknowledgement}

The authors thank to NASA Goddard Space Flight Center for ocean color data (MODIS Aqua/Terra), Institute for Marine Research and Observation, Bali for data processing and research collaboration, and Faculty of Fisheries and Marine Science, Universitas Brawijaya. This research is a part of Hibah Penelitian Unggulan 2020 funded by Institute of Research and Community Services, Universitas Brawijaya.

\section{References}

Barus, T. A., Sinaga, S. S., \& Tarigan, R. (2008). Produktivitas primer fitoplankton dan hubungannya dengan faktor fisik-kimia air di perairan Parapat, Danau Toba. Jurnal Biologi Sumatera, 3(1), $11-16$.

Donlon, C. J., Robinson, I., Casey, K. S., Vazquez-Cuervo J., Armstrong, E., Arino, O., Gentemann, C., May, D., Le Borgne, P., Piollé, J., Barton, I., Beggs, H., Poulter, D. J. S., Merchant, C. J., Bingham, A., Heinz, S., Harris, A., Wick, G., Emery, B., Minnett, P., Evans, R., Llewellyn-Jones, D., Mutlow, C., Reynolds, R. W., Kawamura, H., \& Rayner, N. (2007). The global ocean data assimilation experiment high-resolution sea surface temperature pilot project. Bulletin of the American Meteorological Society, 88, 1197-1213. doi:10.1175/BAMS88-8-1197

Effendi, R., Palloan, P., \& Ihsan, N. (2012). Analisis konsentrasi klorofil-a di perairan sekitar Kota Makassar menggunakan data satelit topex/poseidon. Jurnal Sains dan Pendidikan Fisika, 3, 279-285. doi:10.35580/jspf.v8i3.924

Furuya, K. (1990). Subsurface maximum in the tropical and subtropical western Pacific Ocean: vertical profiles of phytoplankton biomass and its relationship with chlorophyll- $a$ and particulate organic carbon. Marine Biology, 107, 529-539. doi:10.1007/BF01313438

Hastuti, A., Rintaka, W. E., \& Firmansyah, T. (2016). Distribusi suhu, klorofil-a dan nutrien perairan selat bali pada saat muson tenggara. Prosiding Konferensi Nasional IX; Pengelolaan Sumberdaya Pesisir, Laut dan Pulau-Pulau Kecil, 1, 221-234.

Hayati, A., Nureka, T., Mirza, M. F., Putra, I. D. S., Abdizen, M. M., Seta, A. R., Solikha, B. M., Fu'adil, M. H., Putranto, T. W. C., Affandi, M., \& Rosmanida, R. (2017). Water quality and fish diversity in the Brantas River, East Java, Indonesia. Berkala Penelitian Hayati, 22(2), 43-49.

Hendiarti, N., Siegel, H., \& Ohde T. (2004). Investigation of different coastal processes in Indonesian waters using seawifs data. Deep-Sea Research, II 51, 85-97.

Hendiarti, N., Suwarso, Aldrian, E., Amri, K., Andiastuti, R., Sachoemar, S. I., \& Wahyono, I. B. (2005). Seasonal variation of pelagic fish catch around Java. Oceanography, 18, 114-123. doi: $10.1016 / j . d s r 2.2003 .10 .003$

Joesidawati, M. I., Purwanto, \& Asriyanto. (2004). Alternatif pengelolaan perikanan lemuru di Selat Bali (the alternative management for the Bali Strait sardine (lemuru) fishery). Jurnal Pasir Laut, 1(1), 1-19.

Kemili, P., \& Putri, M. R. (2012). Pengaruh durasi dan intensitas upwelling berdasarkan anomali suhu permukaan laut terhadap variabilitas produktivitas primer di perairan indonesia. Jurnal Ilmu dan Teknologi Kelautan Tropis, 4(1): 66-79.

Kunarso, Hadi, S., \& Ningsih, N. S. (2005). Kajian lokasi upwelling untuk penentuan fishing ground potensial ikan tuna. Ilmu Kelautan - Indonesian Journal of Marine Sciences, 10 (2), 6167. doi:10.14710/ik.ijms.10.2.61-67

Merta, I. G. S. (2003). Review of the lemuru fishery in the Bali Straits. In Potier, M., \& Nurhakim, S., BIODYNEX: Biology, Dynamics, Exploitation of the Small Pelagic Fish in the Java Sea, 97-106 Jakarta: MMAF.

Merta, I. G. S. \& Nurhakim S. (2017). Musim penangkapan ikan lemuru (Sardinella lemuru, Bleeker 1853) di perairan Selat Bali. Jurnal Penelitian Perikanan Indonesia, 10, 75. doi: 10.15578/jppi.10.6.2004.75-84
Minnett, P. J., Brown, O. B., Evans, R. H., Key, E. L., Kearns, E. J., Kilpatrick, K., Kuma, A., Maillet, K. A., \& Szczodrak, G. (2004). Sea surface temperature measurements from the Moderate-Resolution Imaging Spectroradiometer (MODIS) on aqua and terra. IEEE International IEEE International IEEE International Geoscience and Remote Sensing Symposium. IGARSS '04. Proceedings. doi: 10.1109/IGARSS.2004.1370173.

Murase, H., Ichihara, M., Yasuma, H., Watanabe, H., Yonezaki, S., Nagashima, H., Kawahara, S., \& Miyashita, K. (2009). Acoustic characterization of biological back-scatterings in the kuroshio-oyashio inter-frontal zone and subarctic waters of the Western North Pacific in spring. Fish Oceanogr, 18, 386-401. doi:10.1111/j.1365-2419.2009.00519.x

NASA Goddard Space Flight Center, Ocean Ecology Laboratory, Ocean Biology Processing Group, 2014. MODIS-Terra Ocean Color Data; NASA Goddard Space Flight Center, Ocean Ecology Laboratory, Ocean Biology Processing Group. http://dx.doi.org/10.5067/TERRA/MODIS_OC.2014.0

Nugroho, S., Akbar, S., \& Vusvitasari R. (2008). Kajian hubungan koefisien korelasi pearson (r), spearman-rho $(\rho)$, kendall - tau $(\tau)$, gamma (g), dan somers (dyx). Jurnal Gradien, 4(2), 372381 .

Putra, E., Gaol, J. L., \& Siregar, V. P. (2012). Relationship chlorophylla concentration and sea surface temperature with primary pelagic fish cathes in Java Sea from modis satellite images. Jurnal Biologi Sumatera, 3, 1-10. doi.org/10.24319/jtpk.3.110

Priyono, B., Yunanto, A., \& Arief T. (2007). Karakteristik oseanografi dalam kaitannya dengan kesuburan perairan di Selat Bali. Balai Riset Dan Observasi Kelautan, Bali.

Rahadian, L. D., Khan, A. M. A., Dewanti, L. P., \& Apriliani, I. M. (2019). Analisis sebaran suhu permukaan laut pada musim barat dan musim timur terhadap produksi hasil tangkap ikan lemuru (Sardinella lemuru) di perairan Selat Bali. Jurnal Perikanan dan Kelautan, 10(2), 28-34.

Robinson, I. S. (2010). Discoveringthe ocean from space the unique applications of satellite oceanography. Berlin Heidelberg: Springer-Verlag.

Sartimbul, A., Nakata, H., Rohadi, E., Yusuf, B., \& Kadarisman, H. P. (2010). Variations in chlorophyll-a concentration and the impact on Sardinella Lemuru catches in Bali Strait, Indonesia. Progress in Oceanography, 87, 168-175. doi:10.1016/j.pocean.2010.09.002

Simbolon, D., Wiryawan, B., Wahyuningrum, P., \& Wahyudi, H. (2011). tingkat pemanfaatan dan pola musim penangkapan ikan lemuru di perairan Selat Bali. Buletin PSP, 19, 242654.

Sofyan, I., Rommie, J., \& Yusni, I. S. (2010). Aplikasi sistem informasi geografis dalam penentuan kesesuaian kawasan keramba jaring tancap dan rumput laut di perairan Pulau Bunguran Kabupaten Natuna. Jurnal Perikanan dan Kelautan, 15(2), 111-120.Susanto, R. D., \& Marra, J. (2005). Effect of the $1997 / 98$ el niño on chlorophyll -a variability along the southern coasts of Java and Sumatra. Oceanography, 18(4), 124-127. doi:10.5670/oceanog.2005.13

Susilo, E. (2015). Variabilitas faktor lingkungan pada habitat ikan lemuru di Selat Bali menggunakan data satelit oseanografi dan pengukuran insitu. Omni-Akuatika, 14(20), $13-22$

Syaifullah, M. D. (2018). Suhu permukaan laut perairan indonesia dan hubungannya dengan pemanasan global. Jurnal Segara, 11(2), 37-47. doi:10.15578/segara.v11i2.

Tran, T. K., Duforět-Gaurier, L., Vantrepotte, V., Ferreira Jorge, D. S., Mériaux, X., Cauvin, A., d'Andon, F,. \& Loisel, H. (2019). Deriving particulate organic carbon in coastal waters from remote sensing: inter-comparison exercise and development of a maximum band-ratio approach. Remote Sensing, 11(23), 2849. doi:10.3390/rs 11232849 .

Walpole, R. E., Myers, R. H., Myers, S. L., \& Ye, K. E. (2012). Probability and statistics for engineers and scientists. international edition. Pearson.

Willige, B. T. (2010). Detection of local site conditions influencing earthquake shaking and secondary effects in Southwest-Haiti using remote sensing and GIS-methods. Nat. Hazards Earth Syst. Sci., 10, 1183-1196. doi:10.5194/nhess-10-11832010, 2010 . 
Yuningsih, H. D., Prijadi, S., \& Sutrisno, A. (2014). Hubungan bahan organik dengan produktivitas perairan pada kawasan tutupan eceng gondok, perairan terbuka dan keramba jaring apung di rawa pening Kabupaten Semarang Jawa Tengah. Diponegoro Journal of Maquares, 3(1), 37-43. doi:10.14710/marj.v3i1.4284
Zahroh, L., \& Sukojo, B. M. (2016). Analisis suhu permukaan laut untuk penentuan daerah potensi ikan menggunakan citra satelit modis level 1b (studi kasus: Selat Bali). Jurnal Teknik ITS, 5 , 2-5. doi:10.12962/j23373539.v5i2.17185 